\title{
Profil Kemampuan Koneksi Matematika Siswa SMP dalam Memecahkan Masalah Matematika Ditinjau dari Gender
}

\author{
Fikri Apriyono \\ IAIN Jember \\ e-mail: fikrimath@ gmail.com
}

\begin{abstract}
ABSTRAK
Penelitian ini bertujuan untuk mendeskripsikan profil kemampuan koneksi matematika dalam memecahkan masalah matematika ditinjau gender. Pemilihan subjek laki-laki dan perempuan berdasarkan tingkat kemampuan yang setara dilihat dari tes kemampuan matematika dan nilai rapor. Penelitian ini menggunakan metode kualitatif dimana data yang diperoleh berupa kata-kata tertulis atau lisan dari orang-orang dan perilaku yang dapat diamati. Teknik pengumpulan datanya dilakukan dengan pemberian tes pemahaman konsep dan wawancara. Dalam penelitian ini diamati siswa laki-laki dan perempuan SMPN 4 Jember kelas VIII. Peneliti melakukan wawancara pada kedua subjek penelitian. Wawancara tersebut direkam kemudian hasilnya ditranskripkan dan dikodekan. Untuk memperoleh data yang valid, data yang diperoleh ditriangulasi. Kemudian data yang valid dianalisis untuk memperoleh kesimpulan. Hasilnya berupa kemampuan koneksi matematika siswa SMP kelas VIII pada materi aljabar dan geometri.
\end{abstract}

Kata kunci: Koneksi Matematika, Memecahkan Masalah, Gender, metode kualitatif

ABSTRACT

This study aimed to describe the profile of mathematics connection ability to solve problems in terms of gender. Selection of male and female subjects based on equal ability level viewed from math skills tests and grades. This study uses a qualitative method where data is obtained in the form of words written or spoken of the people and the behaviors that can be observed. Data collection techniques were conducted by giving the concept understanding tests and interviews. This study observed both boys and girls in class VIII of SMPN 4 Jember. The researcher conducted interviews to both the research subjects. The interview was recorded and then the result was transcribed and coded. To obtain valid data, the data obtained were triangulated. Then the valid data were analyzed to obtain valid conclusions. The result is the mathematics connection ability class VIII of junior high school students of on the algebra and geometry matter. This article illustrates preparation of your paper using MS-WORD. Papers should not be numbered.

Keywords: Connection Mathematics, problem solving, Gender, qualitative method

\section{PENDAHULUAN}

Matematika merupakan ilmu dasar yang berguna bagi kehidupan manusia diantaranya yaitu matematika mendasari perkembangan teknologi modern, matematika mempunyai peran penting dalam berbagai disiplin ilmu dan matematika memajukan daya pikir manusia. Perkembangan pesat di bidang teknologi informasi dan komunikasi saat ini dilandasi oleh perkembangan matematika. Untuk menguasai dan mencipta teknologi di masa depan, diperlukan penguasaan dan pemahaman atas matematika yang kuat sejak dini. Dalam Permendikbud nomor 58 tahun 2014 dijelaskan bahwa salah satu tujuan matematika adalah agar siswa memahami konsep matematika, maka siswa harus menguasai kompetensi dalam menjelaskan keterkaitan antarkonsep dan menggunakan konsep maupun algoritma, secara luwes, akurat, efisien, dan tepat dalam pemecahan masalah. Berdasarkan tujuan tersebut, pembelajaran matematika diharapkan dapat membantu siswa dalam keterkaitan antar 
konsep dari suatu materi. Aktivitas mengaitkan antar konsep matematika tersebut disebut dengan koneksi matematika.

Lebih lanjut, dalam Permendikbud nomor 58 tahun 2014 dijelaskan bahwa salah satu karakteristik matematika yaitu siswa menguasai keterkaitan antara materi yang satu dengan yang lainnya. Materi yang akan dipelajari harus memenuhi atau menguasai materi sebelumnya. Dari pernyataan tersebut jelas sangat penting untuk memahami materi sebelumnya untuk mempelajari materi selanjutnya atau yang disebut dengan koneksi matematika antar konsep.

Kemampuan koneksi matematika bukan hanya berarti mengaitkan antar konsep matematika dengan konsep matematika yang lain. Dalam hal ini, koneksi matematika terdiri dari 3 jenis yaitu mengaitkan antar konsep matematika, konsep matematika dengan ilmu yang lainnya, dan konsep matematika dengan kehidupan sehari-hari (NCTM: 2000). Dapat dikatakan bahwa matematika merupakan pelajaran yang sangat penting karena hampir dalam setiap masalah sehari-hari dapat diselesaikan dengan menggunakan matematika.

Koneksi matematika diperoleh dalam proses kegiatan belajar mengajar matematika. Selama siswa melakukan kegiatan koneksi matematika secara berlanjut atau terusmenerus (continu), siswa akan melihat bahwa matematika bukan hanya serangkaian pengetahuan dan konsep yang terpisah, akan tetapi siswa dapat menggunakan pembelajaran di satu konsep matematika untuk memahami konsep matematika yang lainnya. Dalam arti materi matematika berkaitan dengan materi yang dipelajari sebelumnya. Melalui koneksi matematika diharapkan wawasan dan pemikiran siswa akan semakin terbuka terhadap matematika, tidak hanya terfokus pada topik tertentu yang sedang dipelajari, sehingga akan menimbulkan sikap positif terhadap matematika itu sendiri. Oleh sebab itu sangat penting bagi guru untuk mengajarkan kemampuan koneksi matematika sejak dini agar siswa mampu memahami makna matematika itu sendiri tidak hanya mampu dalam melakukan operasi hitung tertentu.

NCTM (1989: 223) juga menyebutkan pentingnya koneksi matematika bagi siswa, yaitu "... to help student broaden their perspective, to view mathematics as an integrated whole rather than as an isolated set of topics and to acknowledge eits relevance and usefulness both in and out of school'. Koneksi matematika digunakan untuk membantu siswa memperluas perspektif mereka, untuk melihat matematika sebagai suatu keseluruhan yang utuh bukan sebagai serangkaian topik yang terpisah. Apabila siswa dapat menghubungkan konsepkonsep matematika, maka pemahaman mereka akan lebih mendalam dan lebih bertahan lama. Pemahaman siswa akan lebih mendalam terhadap matematika jika siswa dapat mengaitkan antara konsep yang telah diketahui siswa dengan konsep baru yang akan dipelajari oleh siswa.

Hasil penelitian Sugiman (2008:10) mengungkapkan bahwa "rata-rata persentase penguasaan untuk setiap aspek koneksi adalah koneksi inter topik matematika 63\%, antar topik matematika $41 \%$, matematika dengan pelajaran lain $56 \%$, dan matematika dengan kehidupan 55\%". Berdasarkan hasil penelitian Sugiman kemampuan koneksi matematika masih rendah, untuk itu peneliti ingin melihat lebih dalam kemampuan koneksi matematika siswa.

Untuk mengetahui seberapa jauh kemampuan koneksi matematika siswa dapat dilihat dari kemampuan siswa dalam memecahkan masalah matematika. Dengan memecahkan masalah, siswa dapat mengembangkan dan membangun ide-ide, dan berlatih mengintegrasikan konsepkonsep, teorema-teorema dan keterampilan yang dipelajarinya. Selain itu dalam memecahkan masalah, siswa memperoleh 
pengalaman menggunakan pengetahuan serta keterampilan yang telah dimiliki untuk diterapkan pada pemecahan masalah yang tidak rutin.

Kemampuan pemecahan masalah sangat penting dimiliki setiap siswa dalam mempelajari ilmu matematika, hal ini didukung oleh Branca (dalam Sugiman dkk 2009) menyatakan bahwa "Problem solving is the heart of mathematics" yang artinya jantungnya matematika adalah pemecahan masalah. Selanjutnya NCTM (2000) menegaskan bahwa kemampuan pemecahan masalah adalah salah satu aspek penting dalam menjadikan manusia menjadi literat dalam matematika. Dari pendapat di atas dapat dinyatakan bahwa pemecahan masalah merupakan hal yang penting dalam pembelajaran matematika Romberg (dalam Sugiman 2009:1).

Untuk memecahkan masalah matematika, kita dapat menggunakan langkah-langkah pemecahan masalah menurut polya (1973) yaitu 1) memahami masalah; 2) merencakanan penyelesaian; 3) menyelesaikan masalah sesuai rencana dan 4) melakukan pengecekan kembali.

Siswa dalam memecahkan masalah matematika memiliki kemampuan yang beragam tentu berdasarkan tingkat pemahaman siswa terhadap suatu masalah yang dikaitkan dengan konsep yang dimiliki siswa sebelumnya termasuk kemampuan matematika antara anak laki-laki dan perempuan di sekolah.

Maccoby dan Jacklyn (dalam Amir, 2013) mengatakan laki-laki dan perempuan mempunyai perbedaan kemampuan antara lain sebagai berikut: 1) perempuan mempunyai kemampuan verbal lebih tinggi daripada laki-laki. 2) laki-laki lebih unggul dalam kemampuan visual spasial (penglihatan keruangan) dari pada perempuan. 3) laki-laki lebih unggul dalam kemampuan matematika.

Banyaknya penelitian yang dilakukan tentang perbedaan emosional, tingkah laku, pola berfikir dan kecerdasan yang ditunjukkan oleh laki-laki dan perempuan ini. Perbedaan tersebut disebabkan karena kegiatan seharihari antara laki-laki dan perempuan yang berbeda. Pola pikir dan kecerdasan sangat berpengaruh dalam mempelajari matematika terutama kemampuan koneksi matematika yang mengaitkan matematika dengan kehidupan sehari-hari.

Beberapa temuan tentang perbedaan gender dalam pencapaian kemampuan matematika bukan fakta yang baru muncul. Hasil penelitian ini telah menunjukkan bahwa laki-laki lebih baik dalam kemampuan matematika merupakan fenomena universal (Beaton dkk: 1996).

Hasil penelitian Beaton dkk (1996) menunjukkan bahwa anak laki-laki cenderung memperoleh skor yang lebih tinggi dari perempuan pada masalah yang meliputi representasi bangun ruang, pengukuran, dan masalah yang kompleks. Perempuan cenderung memperoleh skor yang lebih tinggi dari laki-laki dalam hal komputasi, masalah yang sederhana, dan membaca grafik.Davis \& Carr (2001) mengemukakan siswa laki-laki lebih menyukai mendapatkan informasi dari memori dan menggunakan strategi kognitif seperti dekomposisi, sementara siswa perempuan lebih menyukai menggunakan strategi yang terbuka seperti menghitung jari atau strategi memanipulasi untuk menyelesaikan masalah matematika.

Penelitian ini difokuskan pada siswa yang memiliki pengetahuan beberapa konsep dasar berdasarkan gender karena peneliti ingin mendeskripsikan koneksi matematika siswa laki-laki dan perempuan.

Demikian pentingnya kemampuan koneksi matematika ini sehingga guru harus sering melatih koneksi matematika siswa terutama pada jenjang Sekolah Menengah Pertama (SMP) sebagai bekal untuk jenjang selanjutnya. 


\section{METODE}

Jenis penelitian ini bertujuan untuk mendeskripsikan profil kemampuan koneksi matematika siswa SMP dalam pemecahan masalah matematika. Berdasarkan tujuan penelitian, maka jenis penelitian ini adalah penelitian deskriptif. Untuk menghasilkan data deskriptif baik berupa kata-kata atau lisan dari setiap subjek, hasil tulisan, dan perilaku yang dapat diamati. Dalam penelitian ini data diperoleh dari hasil pekerjaan siswa yang kemudian dilakukan wawancara berbasis tugas yang bertujuan untuk menggali informasi terhadap segala apa yang dipikirkan dan dilakukan subjek.

Dalam pemilihan subjek, variabel yang perlu dikontrol adalah tingkat kemampuan, sehingga dalam penelitian ini akan dipilih siswa dengan kemampun yang sama atau setara. Kriteria subjek penelitian adalah siswa laki-laki dan perempuan yang memiliki kemampuan sama.

Proses pemilihan subjek penelitian ini dimulai dengan penetapan kelas subjek dan berkonsultasi dengan guru mata pelajaran dalam pemilihan kelas. Peneliti melakukan tes kemampuan matematika terlebih dahulu untuk mendapatkan subjek dengan kemampuan yang relatif sama diantara kedua subjek. Konsultasi dengan guru juga diperlukan untuk memperoleh informasi berkaitan dengan kemampuan komunikasi subjek dalam mengemukakan pendapat secara lisan maupun tulisan.

Peneliti memilih subjek laki-laki dan perempuan berkemampuan tinggi yang relatif sama serta komunikatif dengan maksud kemampuan tinggi telah memiliki konsep dasar yang kuat sehingga mampu untuk dikaitkan dengan ide yang lain maupun dikaitkan dengan kehidupan sehari-hari atau dengan pelajaran yang lain. Adapun alasan lain karena koneksi matematika dan pemecahan masalah membutuhkan kemampuan yang tinggi, sehingga memudahkan peneliti dalam mendeskripsikan kemampuan koneksi matematika pada kedua subjek penelitian tersebut.

Pendekatan penelitian ini adalah penelitian kualitatif, maka peneliti merupakan instrumen utama dalam mengumpulkan data. Selain peneliti sebagai instrumen dalam penelitian ini, peneliti dibantu dengan instrumen pendukung, yaitu (1) instrumen tes kemampuan matematika, (2) instrumen tugas penyelesaian masalah matematika, instrumen pedoman wawancara.

Penentuan subjek penelitian menggunakan TKM. Peneliti menganalisis hasil TKM kemudian mengelompokkan siswa berdasarkan gender, yaitu masingmasing siswa laki-laki dan siswa perempuan. Selanjutnya dianalisis kembali dari siswa lakilaki dan perempuan yang mempunyai kemampuan setara.

Data hasil tes pemecahan masalah dan hasil wawancara dianalisis dengan pendekatan kualitatif. Analisis data dalam penelitian ini menngacu pada beberapa tahapan, yaitu klasifikasi/kategorisasi data, reduksi data, penyajian data, interpretasi/penafsiran data, dan penarikan kesimpulan.

\section{HASIL DAN PEMBAHASAN}

Penelitian ini bertujuan untuk mendiskripsikan kemampuan koneksi matematika siswa SMP dalam memecahkan masalah matematika ditinjau dari gender. Berikut ini adalah hasil penelitian yang telah peneliti lakukan:

1. Profil Kemampuan Koneksi Matematika Siswa Perempuan dalam Memecahkan Masalah Matematika

Pada langkah memahami masalah, kriteria koneksi matematika dengan indikator menjelaskan hubungan antar ideide matematika yang diketahui. Adapun indikator ini dideskripsikan bahwa subjek menyebutkan apa yang diketahui dalam soal kemudian menggambar sehingga membentuk segitiga siku-siku dan 
menuliskan panjang setiap sisi-sisi segitiga sesuai dengan soal. Kriteria koneksi matematika dengan indikator menjelaskan hubungan ide-ide matematika yang diketahui dengan yang ditanya. Adapun indikator ini dideskripsikan bahwa subjek mengemukakan bahwa dengan mengartikan sendiri apa yang ditanyakan pada soal dengan menghubungakan pada gambar yang telah dibuat, dengan pengertian bahwa jarak terdekat iu adalah tinggi dari segitiga siku-siku dengan hipotenusa sebagai alasnya. Penjelasan tersebut didunkung oleh Maccoby dan Jacklyn dalam Amir bahwa perempuan mempunyai kemampuan verbal lebih baik daripada laki-laki.

Pada langkah merencanakan pemecahan masalah, dalam Kriteria koneksi matematika dengan indikator menjelaskan hubungan ide-ide matematika yang dibuat dalam rencana. Adapun indikator ini dideskripsikan bahwa subjek berdasarkan dari konsep yang sudah dikumpulkan subjek menghubungkan dengan konsep lainnya sehingga dapat dibuat sebuah rencana untuk menyelesaikan masalah. Pertama subjek membuat gambar segitiga siku-siku berdasarkan soal yang ada, kemudian menuliskan sisi-sisi yang diketahui dengan yang masih menggunakan variabel. Setelah subjek menggambar maka subjek mulai merencanakan apa yang akan dilakukan, pertama subjek berfikir mencari nilai variabel terlebih dahulu karena tanpa variabel tidak bisa mencari tinggi segitiga. Kemudian menghubungkan antara variabel dengan segitiga siku-siku. Jadi untuk mencari nilai varibel menggunakan triple phytagoras kemudian jika sudah ketemu mengsubtitusikan kedalam variabel tersebut sehingga ketemulah semua sisi segitiga tersebut. Selanjutnya mencari tinggi segitiga jika hipotenusa sebagai alas dari tinggi segitiga yang dicari.
Pada langkah melaksanakan pemecahan masalah, Kriteria koneksi matematika dengan indikator menjelaskan hubungan ide-ide matematika dengan rencana yang ia lakukan. Adapun indikator ini dideskripsikan subjek memecahkan soal sesuai dengan menghubungkan ide-ide matematika yang direncanakan sebelumnya. Subjek menjelaskan langkahlangkah dalam menemukan jawaban dengan disertai alasan-alasanya dalam mengaitkan ide-ide matematika. Langkah pertama yang dilakukan menggambar segitiga siku-siku sesuai dengan yang diperintahkan oleh soal dan mencari maksud apa yang ditanyakan dengan bantuan gambar. Langkah selanjutnya mencari nilai variabel yang belum diketahui dengan mengaitkan ide-ide matematika yang sudah dipahami subjek melaui gambar. Subjek menjelaskan bahwa untuk mencari variabel menggunakan rumus phytagoras sehingga didapatkan persamaan kuadrat. Selanjutnya nilai variabel yang memenuhi persamaan kuadrat tersebut. Untuk mencari nilai variabel yang memenuhi. Subjek menghubungkan matematika dengan kehidupan sehari-hari bahwa tidak ada nilai jarak yang negatif. Subjek menjelaskan bahwa setelah nilai variabel diketahui, selanjutnya mengsubtitusikan nilai variabel kedalam sisi-sisi segitiga sehingga didapat sisi segitiga tanpa mengunakan variabel. Disini subjek menghubungkan informasi yang baru dengan informasi yang sebelumnya. Setelah itu subjek mencari tinggi segitiga dari bantuan gambar subjek menghubungkan luas segitiga dengan tinggi segitiga yang lainnya sehingga didapat nilai dari tinggi atau yang ditanyakan dalam soal tersebut.

Pada langkah memeriksa kembali, dalam kriteria koneksi matematika dengan indikator menjelaskan hubungan apakah 
yang diperoleh sudah sesuai dengan pertanyaan masalah, ide-ide matematika dan strategi. Adapun indikator ini dideskripsikan subjek menghubungkan hasil pengerjaannya sudah sesuai dengan apa yang ditanyakan dalam soal. Untuk mengecek hasil pekerjaan, subjek mengecek dari langkah awal, termasuk rumus-rumus yang digunakan apakah sudah benar, dan menghubungkan antara pertanyaan dengan hasil ataupun pertanyaan dengan gambar. Penjelasan tersebut didukung oleh Amir yang berpendapat bahwa perempuan unggul dalam aspek ketekunan, ketelitian, dan kecermatan.

2. Profil Kemampuan Koneksi Matematika Siswa Laki-laki dalam Memecahkan Masalah Matematika

Pada langkah memahami masalah, dalam kriteria koneksi matematika dengan indikator menjelaskan hubungan antar ideide matematika yang diketahui. Adapun indikator ini dideskripsikan bahwa subjek menyebutkan jarak-jarak yang sudah diketahui dalam soal kemudian menggambar sehingga membentuk segitiga siku-siku. Sedangkan kriteria koneksi matematika dengan indikator menjelaskan hubungan antar ide-ide matematika yang diketahui dengan yang ditanya. Adapun indikator ini dideskripsikan bahwa subjek membuat gambar terlebih dahulu untuk memudahkan apa yang ditanyakan pada soal itu, kemudian mengartikan bahwa jarak yang ditanyakan itu adalah tinggi segitiga lainnya jika sisi miring sebagai alas segitiga.

Pada langkah merencanakan pemecahan masalah, dalam kriteria koneksi matematika dengan indikator menjelaskan hubungan ide-ide matematika yang dibuat dalam rencana. Adapun indikator ini dideskripsikan bahwa subjek berdasarkan dari konsep yang sudah dikumpulkan subjek menghubungkan dengan konsep lainnya sehingga dapat dibuat sebuah rencana untuk menyelesaikan masalah. menyatakan bahwa menjelaskan hubungan konsepkonsep yang dibuat dalam rencana yaitu mencari nilai variabel terlebih dahulu kemudian mengsubtitusikan nilai variabel ke dalam sisi segitiga siku-siku dan mencari tinggi segitiga lainnya dengan sisi miring sebagai alasnya. Subjek juga menjelaskan hubungan materi yang akan digunakan dalam memecahkan masalah yaitu mencari nilai variabel dengan jarakjarak yang terletak pada segitiga siku-siku.

Pada langkah melaksanakan pemecahan masalah, dalam kriteria koneksi matematika dengan indikator menjelaskan hubungan ide-ide matematika dengan rencana yang ia lakukan. Adapun indikator ini dideskripsikan subjek memecahkan soal sesuai dengan menghubungkan ide-ide matematika yang direncanakan sebelumnya. Subjek menjelaskan langkah-langkah dalam menemukan jawaban dengan disertai alasan-alasanya dalam mengaitkan ide-ide matematika. Langkah pertama yang dilakukan membuat simbol arah mata angin kemudian menggambar segitiga siku-siku sesuai dengan yang diperintahkan oleh soal dan mencari maksud apa yang ditanyakan dengan bantuan gambar. Langkah selanjutnya mencari nilai variabel yang belum diketahui dengan mengaitkan konsepkonsep yang sudah dipahami subjek melaui gambar. Subjek menjelaskan bahwa untuk mencari variabel menggunakan rumus phytagoras sehingga didapatkan persamaan kuadrat. Selanjutnya nilai variabel yang memenuhi persamaan kuadrat tersebut. Untuk mencari nilai variabel yang memenuhi. Subjek menghubungkan matematika dengan kehidupan sehari-hari bahwa tidak 
ada nilai jarak yang negatif. Subjek menjelaskan bahwa setelah nilai variabel diketahui, selanjutnya mengsubtitusikan nilai variabel kedalam sisi-sisi segitiga sehingga didapat sisi segitiga tanpa mengunakan variabel. Disini subjek menghubungkan informasi yang baru dengan informasi yang sebelumnya. Setelah itu subjek mencari tinggi segitiga dari bantuan gambar subjek menghubungkan luas segitiga dengan tinggi segitiga yang lainnya sehingga didapat nilai dari tinggi atau yang ditanyakan dalam soal tersebut.

Pada langkah memeriksa kembali, dalam kriteria koneksi matematika dengan indikator menjelaskan hubungan apakah yang diperoleh sudah sesuai dengan pertanyaan masalah, ide matematika dan strategi. Adapun indikator ini dideskripsikan subjek menghubungkan hasil pengerjaannya sudah sesuai dengan apa yang ditanyakan dalam soal. Untuk mengecek hasil pekerjaan, subjek mengecek dari langkah awal, termasuk perhitungan-perhitungan yang digunakan apakah sudah benar, dan menghubungkan antara pertanyaan dengan hasil yang didapat. Amir juga menjelaskan bahwa laki-laki itu lebih unggul dalam hal matematika.

\section{PENUTUP}

\section{Kesimpulan}

Berdasarkan hasil analisis dan pembahasan, peneliti membuat simpulan tentang kemampuan koneksi matematika siswa laki-laki dan perempuan dalam menyelesaikan masalah matematika, sebagai berikut:

1. Kemampuan koneksi siswa perempuan SMP dalam memecahkan masalah matematika didapatkan hasil sebagai berikut: (1) Pada langkah memahami masalah, SP menghubungkan antara ide-ide yang diketahui dengan cara menghubungkan apa yang diketahui dalam soal dengan membentuk segitiga siku-siku dan menuliskan panjang setiap sisi-sisi segitiga sesuai dengan soal. SP juga mengubungkan ide-ide yang diketahui dengan yang ditanya bahwa dengan cara menghubungkan sendiri apa yang ditanyakan pada soal dengan gambar yang telah dibuat dan menghubungkan jarak terdekat itu adalah tinggi dari segitiga siku-siku dengan hipotenusa sebagai alasnya. (2) Pada langkah merencanakan pemecahan masalah, SP menghubungkan ide-ide matematika yang dibuat dalam rencana dengan cara menghubungkan ide matematika dengan ide matematika lainnya sehingga dapat dibuat sebuah rencana untuk menyelesaikan masalah. Pertama subjek membuat gambar segitiga siku-siku berdasarkan soal yang ada, kemudian menuliskan sisisisi yang diketahui dengan yang masih menggunakan variabel. Setelah subjek menggambar maka subjek mulai merencanakan apa yang akan dilakukan, pertama subjek berfikir mencari nilai variabel terlebih dahulu karena tanpa variabel tidak bisa mencari tinggi segitiga. Kemudian menghubungkan antara variabel dengan segitiga siku-siku. Jadi untuk mencari nilai varibel menggunakan triple phytagoras kemudian jika sudah ketemu mengsubtitusikan kedalam variabel tersebut sehingga ketemulah semua sisi segitiga tersebut. Selanjutnya mencari tinggi segitiga jika hipotenusa sebagai alas dari tinggi segitiga yang dicari. (3) Pada langkah melaksanakan pemecahan masalah, subjek memecahkan soal sesuai dengan menghubungkan ideide matematika yang direncanakan 
sebelumnya. Subjek menjelaskan langkah-langkah dalam menemukan jawaban dengan disertai alasanalasanya dalam mengaitkan ide-ide matematika. Langkah pertama yang dilakukan menggambar segitiga sikusiku sesuai dengan yang diperintahkan oleh soal dan mencari maksud apa yang ditanyakan dengan bantuan gambar. Langkah selanjutnya mencari nilai variabel yang belum diketahui dengan mengaitkan konsepkonsep yang sudah dipahami subjek melaui gambar. Subjek menjelaskan bahwa untuk mencari variabel menggunakan rumus phytagoras sehingga didapatkan persamaan kuadrat. Selanjutnya nilai variabel yang memenuhi persamaan kuadrat tersebut. Untuk mencari nilai variabel yang memenuhi. Subjek menghubungkan matematika dengan kehidupan sehari-hari bahwa tidak ada nilai jarak yang negatif. Subjek menjelaskan bahwa setelah nilai variabel diketahui, selanjutnya mengsubtitusikan nilai variabel kedalam sisi-sisi segitiga sehingga didapat sisi segitiga tanpa mengunakan variabel. Disini subjek menghubungkan informasi yang baru dengan informasi yang sebelumnya. Setelah itu subjek mencari tinggi segitiga dari bantuan gambar subjek menghubungkan luas segitiga dengan tinggi segitiga yang lainnya sehingga didapat nilai dari tinggi atau yang ditanyakan dalam soal tersebut. (4) Pada langkah memeriksa kembali, dalam kemampuan koneksi matematika subjek menghubungkan hasil pekerjaan subjek sudah sesuai dengan apa yang ditanyakan dalam soal. Untuk mengecek hasil pekerjaan, subjek mengecek dari langkah awal, termasuk rumus-rumus yang digunakan apakah sudah benar, dan menghubungkan antara pertanyaan dengan hasil ataupun pertanyaan dengan gambar.

2. Kemampuan koneksi siswa perempuan SMP dalam memecahkan masalah matematika didapatkan hasil sebagai berikut: (1) Pada langkah memahami masalah dalam kemampuan koneksi matematika, subjek menghubungkan jarak-jarak yang sudah diketahui dalam soal kemudian menggambar sehingga membentuk segitiga siku-siku. Sedangkan kriteria koneksi matematika dengan indikator menjelaskan hubungan ide-ide matematika yang diketahui dengan yang ditanya. Adapun indikator ini dideskripsikan bahwa subjek membuat gambar terlebih dahulu untuk memudahkan apa yang ditanyakan pada soal itu, kemudian mengartikan bahwa jarak yang ditanyakan itu adalah tinggi segitiga lainnya jika sisi miring sebagai alas segitiga. (2) Pada langkah merencanakan pemecahan masalah dalam kemampuan koneksi matematika, subjek menghubungkan ide matematika dengan dengan ide matematika lainnya sehingga dapat dibuat sebuah rencana untuk menyelesaikan masalah. menyatakan bahwa menjelaskan hubungan ide-ide matematika yang dibuat dalam rencana yaitu mencari nilai variabel terlebih dahulu kemudian mengsubtitusikan nilai variabel ke dalam sisi segitiga siku-siku dan mencari tinggi segitiga lainnya dengan sisi miring sebagai alasnya. Subjek juga menjelaskan hubungan materi yang akan digunakan dalam memecahkan masalah yaitu mencari nilai variabel dengan jarak-jarak yang 
terletak pada segitiga siku-siku. (3) Pada langkah melaksanakan pemecahan masalah dalam kemampuan koneksi matematika, subjek menghubungkan ide-ide matematika yang direncanakan sebelumnya. Subjek menjelaskan langkah-langkah dalam menemukan jawaban dengan disertai alasanalasanya dalam mengaitkan ide-ide matematika. Langkah pertama yang dilakukan membuat simbol arah mata angin kemudian menggambar segitiga siku-siku sesuai dengan yang diperintahkan oleh soal dan mencari maksud apa yang ditanyakan dengan bantuan gambar. Langkah selanjutnya mencari nilai variabel yang belum diketahui dengan mengaitkan konsepkonsep yang sudah dipahami subjek melaui gambar. Subjek menjelaskan bahwa untuk mencari variabel menggunakan rumus phytagoras sehingga didapatkan persamaan kuadrat. Selanjutnya nilai variabel yang memenuhi persamaan kuadrat tersebut. Untuk mencari nilai variabel yang memenuhi. Subjek menghubungkan matematika dengan kehidupan sehari-hari bahwa tidak ada nilai jarak yang negatif. Subjek menjelaskan bahwa setelah nilai variabel diketahui, selanjutnya mengsubtitusikan nilai variabel kedalam sisi-sisi segitiga sehingga didapat sisi segitiga tanpa mengunakan variabel. Disini subjek menghubungkan informasi yang baru dengan informasi yang sebelumnya. Setelah itu subjek mencari tinggi segitiga dari bantuan gambar subjek menghubungkan luas segitiga dengan tinggi segitiga yang lainnya sehingga didapat nilai dari tinggi atau yang ditanyakan dalam soal tersebut. (4) Pada langkah memeriksa kembali dalam kemampuan koneksi matematika, subjek menghubungkan hasil pengerjaannya sudah sesuai dengan apa yang ditanyakan dalam soal. Untuk mengecek hasil pekerjaan, subjek mengecek dari langkah awal, termasuk perhitunganperhitungan yang digunakan apakah sudah benar, dan menghubungkan antara pertanyaan dengan hasil yang didapat.

\section{Saran}

Berdasarkan kesimpulan hasil penelitian di atas, beberapa saran yang dapat dikemukakan adalah sebagai berikut.

1. Dari hasil penelitian ini, didapat informasi profil kemampuan koneksi matematika siswa SMP kelas VIII bahwa subjek merasa kesulitan dalam mengaitkan ide-ide yang diketahui, hal ini terlihat pada saat setelah subjek membaca soal butuh waktu lama untuk memahami soal tersebut. Sehingga diharapkan kepada para pendidik untuk mempertimbangkan informasi tersebut dalam pembelajaran di kelas dan membiasakan siswa pada soal pemecahan masalah yang mengaitkan beberapa konsep dalam satu materi.

2. Tugas Pemecahan Masalah (TPM) yang digunakan kurang mewakili permasalahan matematika yang ada karena hanya terbatas pada materi aljabar dan geometri. Sehingga untuk penelitian selanjutnya diharapkan materi yang digunakan dapat lebih luas cangkupannya sehingga dapat mewakili permasalahan matematika yang ada.

3. Subjek penelitian ini hanya siswa perempuan dan laki-laki yang memiliki kemampuan setara pada kelompok matematika tinggi, sehingga pada penelitian selanjutnya 
diharapkan seluruh kemampuan tingkatan kemampuan matematika tinggi, sedang dan rendah dapat terwakili.

4. Keterbatasan indikator yang dibahas dalam penelitian ini karena kurangnya data yang diperoleh. Sehingga untuk penelitian selanjutnya diharapkan mampu membahas semua indikator.

\section{DAFTAR PUSTAKA}

Amir, Z. (2013). Perspektif Gender Dalam Pembelajaran Matematika. [online]. http://portalgaruda.org . 5 Maret2015

Beaton, Mullis, Martin, Gonzales, Kelli, Smith. (1996). Mathematics Achievement in the Middle School Years: IEA's Third International Mathematics and Science Study (TIMSS). Chestnut Hill, MA: TIMSS International Study Center Boston Coolege

Davis, H. \&Carr, M. (2001). Gender Differences in Arithmetic Strategy Use:A Function of Skill and Preference. [online] . http://www.idealibrary.com . 4 Januari 2015

National Council of Teacher of Mathematics (NCTM). (2000). Principles and Standards for School Mathematics. Washington D.C: National Academy Press.

Peraturan Menteri Pendidikan dan Kebudayaan Republik Indonesia Nomor 58 Tahun 2014 Tentang Kurikulum $2013 \quad$ SMP/MTs. Kementerian Pendidikan dan Kebudayaan.

Polya, G.(1973). How to Solve It. New Jearsey: Princeton University.

Sugiman.(2008).Koneksi Matematik dalam Pembelajaran Matematika di Sekolah Menengah Pertama. [online]. http://staff.uny.ac.id/sites/default/fil es/131930135/2008_Koneksi_Mat.p df Didownload 8 Desember 2014

Sugiman, Kusumah. Y.S,\& Sabandar. J. (2009). Pemecahan Masalah Matematik Dalam Matematika Realistik. [online]. http://staff.uny.ac.id/sites/default/fil es/131930135/2009a_PM_dalam_P MR.pdf Didownload 3 Maret 2015

\section{RIWAYAT HIDUP PENULIS}

Fikri Apriyono, M.Pd. Lahir di Jember, 1

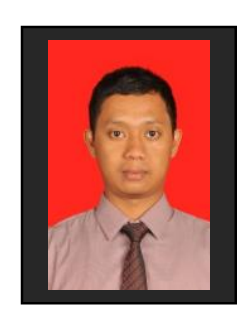
April 1988. Dosen Tetap di IAIN Jember. Studi S1 Pendidikan Matematika Universitas Jember, lulus tahun 2011; dan S2 Pendidikan Matematika Universitas Negeri

Surabaya, lulus tahun 2015. 